\title{
LOCK DOWN ON THE THIRD SCREEN: HOW WIRELESS CARRIERS EVADE REgULATION OF THEIR VIDEO SERVICES
}

\author{
By Rob Frieden ${ }^{\dagger}$
}

\section{TABLE OF ConTENTS}

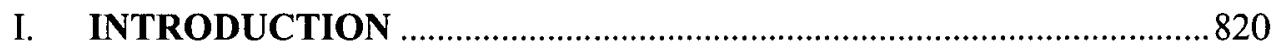

II. THE REGULATORY QUANDARY PRESENTED BY THIRD SCREEN CONVERGENCE

III. WIRELESS CARRIERS' INCENTIVE AND ABILITY TO LOCK DOWN ACCESS.

IV. CURBING CABLE TELEVISION MARKET POWER IN VIDEO PROGRAMMING ACCESS

A. BAN ON EXClusive CONTRACTS BETWEEN PROGRAMMERS AND CABLE OPERATORS

B. Prohibition ON CONTENT TIER-BUY THROUGH REQUIREMENTS

C. FORCED ALTERNATIVES TO MANDATORY SET TOP BOX LEASES.........832

V. REASONS WHY WIRELESS CARRIERS SHOULD BEAR CONTENT NONDISCRIMINATION REQUIREMENTS LIKE THOSE BORNE BY CABLE OPERATORS

A. PuBliC BENEFITS AND HARMS FROM BUNDLING WIRELESS SERVICE WITH HANDSETS

B. THE WIRELESS CARRIER MARKETPLACE IS AS CONCENTRATED AND ANTICOMPETITIVE AS CABLE TELEVISION

C. INCENTIVES AND REWARDS FROM WIRELESS WALLED GARDENS.

VI. THE RELEVANCE OF THE INTERNET FOUR- FREEDOMS POLICY IN THE COMCAST ORDER

A. APPL YING THE FOUR FREEDOMS TO NETWORK INTERFERENCE 839

(C) 2009 Rob Frieden

$\dagger$ Pioneers Chair and Professor of Telecommunications and Law, Pennsylvania State University. 
B. ESTABLISHING FCC JURISDICTION OVER INTERNET-BASED PRACTICES .843

C. REMEDYING BREACHES OF THE INTERNET NONDISCRIMINATION POLICY. .845

\section{ACHIEVING A LEVEL PLAYING FIELD AND SERVING} THE PUBLIC INTEREST 846

\section{INTRODUCTION}

Wireless handsets increasingly deliver more than tetherless telephone calls, text messaging, and ringtones. Next generation networks, and the sophisticated handsets that access them, offer a variety of new information, communications, and entertainment ("ICE") services. Wireless handsets have begun to work more like mobile computers by providing consumers with a "third screen" alternative for accessing multimedia content also available from television sets and personal computer monitors. ${ }^{1}$

The wireless third screen has the potential to offer users mobile access to everything the Internet offers. However, it has become clear that most wireless carriers have a financial interest in steering subscribers to a more limited "walled garden" of content and software applications. Walled gardens provide carrier-delivered content to subscribers in a user-friendly, expedited basis. For example, a wireless carrier might offer access to a preferred search engine or source of content by offering a one step process. Subscribers seeking to access non-preferred content typically would have to undertake several additional steps that may add time, complexity, inconvenience, and possibly higher cost in the determination of whether to seek alternatives to walled garden options. Subscribers have access to walled garden content available from the carrier, an affiliate of the carrier, or a third party that has secured preferential access to the carrier's subscribers in exchange for sharing revenues. Unlike computer terminals where users have easy and unfettered opportunities to exit the carrier's walled garden, wireless subscribers may experience difficulty and incur additional costs when departing from wireless carriers' walled gardens. For example, Apple Computer, Inc. and AT\&T, the exclusive United States vendor for the iPhone, offer an apparently quite generous walled garden containing over 30,000 applications that provide subscribers a variety of new options for accessing

1. See, e.g., Nick Wingfield, Time to Leave the Laptop Behind, WALL ST. J., Oct. 27, 2008 , at R1.

2. In re Implementation of Section 6002(B) of the Omnibus Budget Reconciliation Act of 1993, 23 F.C.C.R. 2241, 2315 (2008). 
content and services. ${ }^{3}$ But computer users would object to any software or content access limitation, including the obligation to use a single carriersupplied interface to acquire that software, if an Internet Service Provider ("ISP") or a wired telephone company tried to establish such restrictions. Likewise, television owners would not tolerate any limitation on the devices they attach for accessing live or prerecorded content. The limits that wireless carriers impose on handset use starkly contrast with what carriers in other industries impose. ISPs have limited control over users' computer terminals, and video programmers have no power to restrict how television owners use their receivers to access programming. In contrast, wireless carriers can and do impose substantial operational limitations on handset use. Some of these restrictions represent necessary safeguards in light of the fact that wireless handsets use radio spectrum and require a technical interface to access specified channels using a predetermined format. However, most restrictions result from carriers' efforts to recoup financial subsidies given for handsets sold in conjunction with new or renewed service agreements. Additionally, carriers seek strategic opportunities to squeeze out more revenues per subscriber, to prevent migration to the services of another carrier, and to keep subscribers within the confines of a carrier's walled garden.

In the United States, the Communications Act of 1934, as amended, establishes separate definitions ${ }^{4}$ for telecommunications, ${ }^{5}$ information, ${ }^{6}$ and cable television services. ${ }^{7}$ The FCC appears unable to apply two or more regulatory classifications to the same operator when it provides more than one category of service. ${ }^{8}$ Converging technologies and markets all but guar-

3. See Apple, Inc., App Store and Applications for iPhone, http://www.apple.com/ iphone/appstore/ (last visited April 27, 2009).

4. In re Fed.-State Joint Bd. on Universal Serv., 13 F.C.C.R. 11501, 11522 (1998) ("[T]he language and legislative history of [the Communications Act of 1996] indicate that the drafters ... regarded telecommunications services and information services as mutually exclusive categories."); see also Vonage Holdings Corp. v. Minn. Pub. Utils. Comm'n, 290 F. Supp. 2d 993, 1000 (D. Minn. 2003) (applying the FCC's dichotomy).

5. 47 U.S.C. $\S 153(43),(44),(46)$ (2006).

6. 47 U.S.C. $\S 153(20)(2006)$.

7. 47 U.S.C. $\S 522(6),(7),(20)(2006)$.

8. Technological and market convergence increasingly makes it difficult for the FCC to assign services into mutually exclusive categories, a task it considers compulsory. "[T]he language and legislative history of [the Communications Act of 1996] indicate that the drafters ... regarded telecommunications services and information services as mutually exclusive categories." Federal-State Joint Board on Universal Service, Report to Congress, 13 F.C.C.R. 11501, 11522 (1998); see also Vonage Holdings Corp., 290 F. Supp. 2d at 994, 1000 (applying the FCC's dichotomy). "In keeping with the legislative history of the Communications Act, the Commission interprets that Act's definitions of 'telecommunications service' and 'information service' to be mutually exclusive." Communications Assis- 
antee that operators will seek to expand their array of services to include both regulated telecommunications and other less regulated video and information services. ${ }^{9}$ For example, a wireless carrier that provides conventional telephone services, treated as a regulated telecommunications service, also may offer Internet access, treated as a largely unregulated information service, and video services that trigger different types of regulations than telephone services. The Federal Communications Commission ("FCC") has evidenced an inability to apply two different regulatory regimes to the same venture when it offers services that trigger more than one regulatory classification, choosing instead to classify most ventures in the loosely regulated "information category." Accordingly, the FCC treats wireless carriers as qualifying for largely unregulated status, despite the fact that these carriers continue to provide regulated telecommunications services and offer video programming that could readily fit within the cable classification.

This Article will examine the regulatory status of wireless carrierdelivered video content with an eye toward determining the necessary scope and nature of government oversight. Past practices of the FCC in regulating the cable industry are examined to highlight the disparate treatment of wireless-delivered video content, despite the fact that both ventures distribute identical or similar content. The Article concludes that the FCC must balance the carriers' interests in finding new revenue centers to pay for next generation network upgrades with the subscribers' interests in having maximum freedom to use handsets they own. The Commission should help promote wireless carriers' exploitation of technological and marketplace innovations that make it possible to provide a combination of telecommunications, information, and video programming services. But regulators also must guard against anticompetitive strategies designed to favor carrier ICE

tance for Law Enforcement Act and Broadband Access And Services, ET Docket No. 04295, RM-10865, First Report and Order and Further Notice of Proposed Rulemaking, 20 F.C.C.R. 14989, 14996 (2005) (citing Federal-State Joint Board on Universal Service, CC Docket No. 96-45, Report to Congress, 13 F.C.C.R. 11501, 11520, 11522-23 १⿻ 39, 43 (1998)).

9. "Over the last two decades, the communications industry has undergone rapid technological advancements leading to the convergence of services. New technological capabilities allow companies to compete in markets which previously had no competition. While potentially beneficial to the consumer, convergence within the communications industry has created a regulatory nightmare." Ryan K. Mullady, Regulatory Disparity: The Constitutional Implications of Communications Regulations That Prevent Competitive Neutrality, 2 U. PITTSBURGH J. TECH. L. \& POL'Y 4 (2007). For background on the impact of converging telecommunications and information processing technologies see, for example, International Telecommunication Union, ITU Internet Report 2006, digital.life; available at http://www.itu.int/osg/spu/publications/digitalife/ index.html. 
services by handicapping access to alternative sources. The Article concludes that because the FCC considers it necessary to promote video programming competition and access for wired cable television ventures, the Commission must undertake similar efforts to promote wireless access because wireless carriers have equivalent incentives and capabilities to blunt competition.

\section{THE REGULATORY QUANDARY PRESENTED BY THIRD SCREEN CONVERGENCE}

The versatility of modern wireless handsets presents a regulatory quandary for the FCC. Innovations in wireless handsets make it possible for devices to provide access to a variety of ICE services that include telephone calls, information services, e-commerce applications, position location functions, as well as access to the Internet and video programming. Wireless handsets have become an electronic Swiss Army knife capable of exploiting ICE convergence and easily toggling between first, second, and third generation wireless functions. In the first generation of wireless handsets, users made mobile telephone calls almost exclusively. With digitization in the second generation, subscribers could engage in text messaging, photography, music downloading, and other functions that rely on memory storage, keypads, and video screens. In the evolving third generation, ${ }^{10}$ the wireless handset can switch between legacy functions, such as conventional voice telephony, and new features, such as broadband Internet access, that can convert the handset into a versatile platform for accessing most multimedia content. ${ }^{11}$

The FCC appears ill-equipped to apply different regulatory regimes to third generation wireless ventures capable of shifting functions. Prior to the onset of robust technological and market convergence, the FCC could enact different and mutually exclusive regulations based on the single set of services any one enterprise offered. The Commission established different regulatory requirements for broadcasters, cable television operators, telephone companies, and ISPs based on the specific characteristics of each type operator. The FCC has yet to address the impact of convergence that makes it possible for wireless carriers to offer a combination of services, accessed by

10. In re Serv. Rules for Advanced Wireless Servs. in the $1.7 \mathrm{GHz} \& 2.1 \mathrm{GHz}$ Bands, 18 F.C.C.R. 25162, 25163 n.1 (2003) (describing the different generations of wireless technology).

11. Ed Rosenberg, Nat'l Regulatory Research Inst., Assessing Wireless and Broadband Substitution in Local Telephone Markets, (2007), http://nrri.org/pubs/ telecommunications/07-06.pdf. 
a single wireless device, that run the gamut of these regulatory classifications.

To make matters even more complicated in the wireless marketplace, vertically integrated wireless carriers blend content and conduit, making it all but impossible to establish "bright line" regulatory demarcations between the provision of telecommunications transmission services and the content these links transmit. In previous regulatory regimes, the FCC could separate the content provider from the content carrier, subjecting the former to little, if any, government oversight while subjecting the latter to extensive common carrier price, quality of service, and nondiscrimination regulation.

Using congressionally crafted service definitions, ${ }^{12}$ the FCC applies the largely unregulated information services category to as many convergence services as plausible with an eye toward promoting marketplace-driven competition and innovation largely free of government oversight. ${ }^{13}$ Traditionally, "information services" would be applied to providers of multimedia services while the heavily regulated "telecommunications" category would be applied to wireless carriers. The FCC has opted to ignore or subordinate the conduit function provided by wireless carriers providing multimedia services, which if separately identified would trigger the obligation for the Commission to enforce the more extensive regulations applied to telecommunications service providers. When wireless carriers offer a convergent blend of telecommunications access to telephony, video content, and information services, the FCC emphasizes the multimedia service delivered to subscribers' wireless handsets and deemphasizes the fact that the wireless carriers use a telecommunications network to deliver such content. ${ }^{14}$ Reviewing courts have endorsed this regulatory and semantic sleight of hand. ${ }^{15}$

The FCC, while evidencing a preference to treat convergent services as "information services," has inconsistently applied legislatively crafted definitions with an eye toward exempting some convergent services while regulating others. The FCC gladly deregulated all forms of wireline and wireless

12. See supra notes $5-6$.

13. See, e.g., In re Appropriate Regulatory Treatment for Broadband Access to the Internet Over Wireless Networks, 22 F.C.C.R. 5901 (2007).

14. In re Inquiry Concerning High-Speed Access to the Internet over Cable \& Other Facilities, 17 F.C.C.R. 4798 (2002), aff'd sub nom. Nat'l Cable \& Telecomms. Ass'n v. Brand X Internet Servs., 545 U.S. 967 (2005).

15. Nat'l Cable \& Telecomms. Ass'n v. Brand X Internet Servs., 545 U.S. 967 (2005) (upholding the FCC's determination that cable modem provided Internet access constitutes an information service); see also Rob Frieden, What Do Pizza Delivery and Information Services Have in Common? Lessons From Recent Judicial and Regulatory Struggles with Convergence, 32 RUTGERS COMPUTER \& TECH. L.J. 247 (2006). 
broadband access, but has not extended this regulatory forbearance to Voice over the Internet Protocol ("VoIP") ${ }^{16}$ telephony and Internet Protocol Television ("IPTV"). ${ }^{17}$ These services seamlessly blend telecommunications transmission links with information services, but the FCC appears inclined to avoid applying the unregulated information services classification, because these services compete directly with pre-existing ("legacy") common carrier telephone and television service. Rather than treat VoIP carriers with the same sort of regulatory forbearance it applies to wireless telephone service, and increasingly to wireline service, the FCC has saddled VoIP service with regulatory burdens that make VoIP service more like conventional telephone service, at the expense of reducing VoIP's competitive cost advantage. ${ }^{18}$ VoIP service providers, which offer subscribers telephone calling access to the conventional wireline public switched telephone network ("PSTN"), must contribute to universal service funding, ${ }^{19}$ reconfigure their service to provide wiretapping capabilities to law enforcement authorities, ${ }^{20}$ provide caller location identification and emergency 911 access $^{21}$ and offer service to disabled users. ${ }^{22}$ Despite extensive rhetoric about refraining from imposing regulation on both emerging technologies and competitive services, ${ }^{23}$ the FCC imposed these traditional regulatory burdens, choosing not

16. Voice over the Internet Protocol ("VoIP") offers voice communications capabilities, much like ordinary telephone service, using the packet switched Internet, for all or part of the link between call originator and call recipient.

17. Internet Protocol Television ("IPTV") offers access to video programming via the Internet. Users can download files that contain such content for subsequent viewing. Alternatively they can receive an online "stream" of video packets corresponding to an existing file, or a simulcast of "live" programming.

18. See Rob Frieden, Neither Fish Nor Fowl: New Strategies for Selective Regulation of Information Services, 6 J. TELECOMM. \& HIGH TECH L. 373 (2008).

19. In re Universal Serv. Contribution Methodology, 21 F.C.C.R. 7518, 7538 (2006) (extending section 254 (d) permissive authority to require interconnected VoIP providers to contribute to the USF), reh' $g$ denied, vacated in part on other grounds, Vonage Holding Corp. v. FCC, 489 F.3d 1232 (D.C. Cir. 2007).

20. In re Commc'ns Assistance for Law Enforcement Act \& Broadband Access \& Servs., 20 F.C.C.R. 14989 (2005), petition for rev. denied, 451 F.3d 226 (D.C. Cir. 2006).

21. In re IP-Enabled Servs., 20 F.C.C.R. 10245 (2005), petition for rev. denied, 473 F.3d 302 (D.C. Cir. 2006).

22. In re IP-Enabled Servs., 22 F.C.C.R. 11275 (2007), rev'd, 22 F.C.C.R. 18319 (2007) (granting in part and denying in part waivers of the FCC order).

23. Telecommunications Act of 1996, Pub. L. No. 104-104, § 706, 110 Stat. 56, 153 (codified as amended 47 U.S.C. $\S 157$ note (2006)) (requiring the FCC to encourage the deployment of advanced telecommunications capability to all Americans by using regulating methods that remove barriers to infrastructure investment); In re Appropriate Regulatory Treatment for Broadband Access to the Internet Over Wireless Networks, 22 F.C.C.R. 5901,5911 (2007) (classifying wireless broadband Internet access as a lightly regulated information service to "help spur growth and deployment of these services"); see also 47 
to allow the marketplace to determine whether the considerable service discounts available from VoIP service providers outweigh the greater risk in an emergency and greater inconvenience for some users.

The FCC has largely accepted the view that wireless carriers need to qualify for a deregulated "safe harbor" ${ }^{24}$ so that sufficient incentives exist for these carriers to invest in next generation infrastructure and spectrum auctions. ${ }^{25}$ This preoccupation with incentive creation ignores the likely probability that incumbent wireless carriers would invest in any new spectrum to foreclose market entry by new competitors. The attractiveness of investing in wireless technology is illustrated by the growing reliance of incumbent wireline carriers on wireless services to generate revenues in light of declines in previous core market segments, e.g., local and long distance telephone service.

\section{WIRELESS CARRIERS' INCENTIVE AND ABILITY TO LOCK DOWN ACCESS}

The FCC's willingness to allow wireless carriers to deprive subscribers of the access freedoms mandated for wire-based carriers caters to the wireless carriers' large financial incentive to impose limits on handsets, and keen interest in avoiding rules that could impair their ability to maintain such limits. Wireless carriers have invested billions of dollars in the spectrum $^{26}$ and infrastructure needed to provide third generation network services. Additionally, these carriers typically combine wireless service with offers of a subsidized handset in exchange for a two year service commitment by subscribers. In light of such risk taking, these carriers predictably seek to evade, or at least limit, any government regulatory oversight that might constrain their ability to recoup their handset subsidies and network

U.S.C. $\S \S 157,230(b)(2)(2006)$ (stating that it is the policy of the United States "to preserve the vibrant and competitive free market that presently exists for the Internet").

24. BLACK's LAW DICTIONARY 1363 (8th ed. 2004) (defining a safe harbor to be "[a]n area or means of protection [or a] provision (as in a statute or regulation) that affords protection from liability or penalty.").

25. In re Appropriate Framework for Broadband Access to the Internet Over Wireline Facilities, 20 F.C.C.R. 14853, 14878 (2005) ("[W]e seek to adopt a comprehensive policy that ensures ... that broadband Internet access services are available to all Americans and that undue regulation does not constrain incentives to invest in and deploy the infrastructure needed to deliver broadband Internet access services").

26. See FCC, Auctions Summary, http://wireless.fcc.gov/auctions/default.htm?job= auctions_all (last modified Nov. 10, 2008). 
facilities investment, particularly by diversifying services and increasing the monthly average return per user ("ARPU").

However, the requirement that common carriers operate in a nondiscriminatory manner constitutes a fundamental component of conventional common carrier telecommunications service regulation and should apply to wireless carriers when they provide voice telephone services. ${ }^{27}$ Title II of the Communications Act of 1934, as amended, requires telecommunications service providers, inter alia, to charge just and reasonable rates, to operate in a nondiscriminatory manner, and to submit to scrutiny by the FCC to resolve consumer complaints. In their capacity as information and video programming providers, wireless carriers do not trigger conventional telephone service common carrier regulation. The FCC can forbear from applying any of the common carrier regulations to wireless carriers only upon determining that consumers will remain protected against unreasonable and discriminatory practices and that the public interest supports forbearance. ${ }^{28}$ Wireless carriers want the FCC and the public to conclude that even though wireless carriers still must comply with most Title II common carrier telecommunications service regulations, ${ }^{29}$ the FCC nevertheless should refrain from enforcing the rules in light of the fact that the carriers also offer multimedia services which qualify for the largely unregulated "information services" category.

Wireless carriers should not qualify for exemption from common carrier regulation $^{30}$ simply because a portion of what they offer does qualify for comparatively less regulatory oversight than their telecommunications service. Nevertheless, a prominent Wall Street Journal industry analyst has concluded that the wireless carriers have succeeded in creating the inference that they cannot be regulated:

A shortsighted and often just plain stupid federal government has allowed itself to be bullied and fooled by a handful of big wireless

27. The FCC uses the term Commercial Mobile Radio Service ("CMRS") to identify the basic telephone services provided by wireless carriers. See Omnibus Budget Reconciliation Act of 1993, Pub. L. No. 103-66, §6002, 107 Stat. 312, 393 (codified as amended at 47 U.S.C. $\S 332$ (2006)) (creating the CMRS carrier category).

28. 47 U.S.C. $\S 332$ (c)(1)(A)(i)-(iii) (2006); see also 47 U.S.C. $\$ 160$ (a) (2006) (establishing similar forbearance criteria for other telecommunications service providers).

29. 47 U.S.C. $\S \S 201-276$ (2006).

30. Despite having a statutory duty to regulate cellular telephone carriers as common carriers, the FCC rarely acknowledges and acts on this requirement. See In re Reexamination of Roaming Obligations of Commercial Mobile Radio Serv. Providers, 22 F.C.C.R. 15817,15818 (2007) (specifying that cellular operators must provide their subscribers automatic access to other carriers to for making and receiving telephone calls when traveling outside subscribers' home service regions). 
phone operators for decades now. And the result has been a mobile phone system that is the direct opposite of the PC model. It severely limits consumer choice, stifles innovation, crushes entrepreneurship, and has made the U.S. the laughingstock of the mobile-technology world, just as the cellphone is morphing into a powerful hand-held computer.... That's why I refer to the big cellphone carriers as the "Soviet ministries." Like the old bureaucracies of communism, they sit athwart the market, breaking the link between the producers of goods and services and the people who use them. ${ }^{31}$

In this light, the FCC all the more needs to remedy carriers' tactics that are detrimental to market competition. Instead, the FCC strongly prefers to shoehorn any and all converged services into the lightly regulated information services "safe harbor," including wireless broadband Internet access service. ${ }^{32}$ With rare exception, the FCC appears reluctant to hold wireless operators to the still applicable Title II requirements, despite having not untaken the examination necessary to forbear officially from regulating. ${ }^{33}$ The FCC has evidenced an inability to subject wireless carriers to multiple regulatory regimes based on the fact that these carriers trigger different regulatory scrutiny when providing different services. Without undertaking the appropriate administrative process to forbear from regulating wireless carriers under Title II, the FCC simply refrains from providing the necessary scrutiny. Regardless of the regulatory posture undertaken by the FCC, or what regulatory classification the FCC applies to particular wireless services, fundamental public interest and consumer protection concerns require the FCC to assess whether wireless carriers have the incentive and ability to discriminate unlawfully and to regulate appropriately. Wireless carriers' efforts $^{34}$ to frame the debate in terms of whether their broadband and video

31. Posting of Walt Mossberg to All Things Digital (Mossblog), Free My Phone, http://mossblog.allthingsd.com/20071021/free-my-phone/ (Oct. 21, 2007, 21:31 PT).

32. See In re Appropriate Regulatory Treatment for Broadband Access to the Internet Over Wireless Networks, 22 F.C.C.R. 5901 (2007).

33. 47 U.S.C. $\S 160(a)(1)-(3)$ (2006) (authorizing the FCC to forbear from applying specific aspects of Title II regulation if enforcement only upon determining that consumers will remain protected against unreasonable and discriminatory service and that the public interest supports forbearance); see also, MCI Telecomms. Corp. v. Am. Tel. \& Tel. Co., 512 U.S. 218 (1994) (absent explicit legislative authorization the FCC could not exempt designated "nondominant" carriers from the Communications Act's Title II requirement that all carriers file a public contract, known as a tariff, specifying the terms and conditions of service).

34. In re Appropriate Regulatory Treatment for Broadband Access to the Internet Over Wireless Networks, 22 F.C.C.R. 5901, 5905-06 (2007) ("Cingular Wireless \& BellSouth and Cisco contended that wireless broadband Internet access service should be classi- 
programming services qualify for deregulation as information services largely shifts attention from the real problem, which is whether government oversight remains legislatively mandated and necessary, or whether a fully competitive and self-regulating marketplace exists. In the following Parts, the Article will draw analogies from the FCC's regulation of similar industries to show that regulation of the wireless carriers remains consistent with FCC policy and practice. When cable television ventures attempt to favor corporate affiliates, or stifle competition in the delivery of, and access to, video programming, the FCC has aggressively intervened.

\section{CURBING CABLE TELEVISION MARKET POWER IN VIDEO PROGRAMMING ACCESS}

The FCC's aggressive and expanding regulation of cable companies stands in sharp contrast with its reluctance to enforce valid regulations of wireless carriers, despite the similarity of content provided to consumers. For over several decades, the FCC has expressed concerns that cable television ventures can and will harm consumers by establishing vertically integrated firms ${ }^{35}$ that create and distribute "must-see" content, while limiting access to multi-channel video programming distributor ("MVPD") competitors. The major cable television companies both create and distribute video programming. The FCC attempts to restrict the power of cable companies which have every financial incentive to constrain consumers' choice of video programming available from competitors.

In 2007 , the FCC specifically found that cable companies tied programming and distribution in ways that reduced the programming available to MVPD competitors:

[W]e conclude that there are no good substitutes for some satellite-delivered vertically integrated programming and that such

fied as an information service, asserting that the deregulatory features of CMRS allowed under section 332 were not sufficient.").

35. Vertical integration refers to the combination of separate market activities by a single enterprise. In re Annual Assessment of the Status of Competition in the Market for the Delivery of Video Programming, 21 F.C.C.R. 2503, 2575 (2006) ("Vertical relationships may have beneficial effects, or they may deter competitive entry in the video marketplace and/or limit the diversity of programming."); $i d$. at $2575 \mathrm{n} .565$ ("Beneficial effects can include efficiencies in the production, distribution, and marketing of video programming, and providing incentives to expand channel capacity and create new programming by lowering the risks associated with program production ventures"); id. at $2575 \mathrm{n} .566$ ("Possible detrimental effects can include unfair methods of competition, discriminatory conduct, and exclusive contracts that are the result of coercive activity."). 
programming therefore remains necessary for viable competition in the video distribution market. Based on this finding, we conclude that vertically integrated programmers continue to have the ability to favor their affiliated cable operators over competitive MVPDs such that competition and diversity in the distribution of video programming would not be preserved and protected absent the rule. Although we find some trends in the markets for both video programming and video distribution since 2002 that might decrease the incentive of vertically integrated programmers to withhold programming from competitive MVPDs, we also find some trends that increase their incentive to withhold programming, such as the increase in horizontal consolidation of the cable industry, the increase in cable clustering, and the recent emergence of new competitors. We also find specific factual evidence that, where the exclusive contract prohibition does not apply, such as in the case of terrestrially delivered programming, vertically integrated programmers have withheld and continue to withhold programming from competitive MVPDs. ${ }^{36}$

Because cable television companies generate most of the desired video content and control the major medium for distributing that content, the FCC expressed concern that the cable companies can thwart competition, favor affiliated content providers, stifle the development of new content sources and extract rates above competitive levels from subscribers. ${ }^{37}$

\section{A. Ban on Exclusive Contracts between Programmers and Cable Operators}

Troubled by the power of cable television ventures to stifle consumer access to content, the FCC decided to extend a ban on exclusive contracts between vertically integrated programmers and cable operators for five additional years, until October $5,2012{ }^{38}$ The FCC determined that vertically integrated programmers still have the ability ${ }^{39}$ and the incentive ${ }^{40}$ to favor

36. In re Implementation of the Cable Television Consumer Protection \& Competition Act of 1992, 22 F.C.C.R. 17791, 17810 (2007).

37. Id. at 17816 (expressing concern over vertically integrated cable operators).

38. Id. at 17792 (finding that the exclusive contract prohibition was necessary "to preserve and protect competition and diversity in the distribution of video programming").

39. Id. at 17814-15 (expressing the commission's concern that the four largest cable MSOs have an interest in the top networks as ranked by subscribership).

40. Id. at 17821 (describing how an exclusive arrangement between a cable-affiliated programmer and its affiliated cable operator will increase the number of subscribers when customers switch to the affiliated able distribution service in order to receive the exclusive programming). 
corporate affiliates over other competitive providers. ${ }^{41}$ The FCC reaffirmed its conclusion that vertically integrated ventures still control the "must see" content, for which no viable substitute exits. ${ }^{42}$ The FCC retained the prohibition against exclusive content distribution contracts from ventures that vertically integrate content production and distribution to consumers.

The FCC showed strong resistance to vertically integrated carriers' control of content provided to users. The FCC rejected programmer suggestions to narrow its ban on exclusive contracts so that restrictions would vary with the popularity of the programming network and the competitive climate in specific regions served by a cable operator. ${ }^{43}$ Additionally the FCC refused to limit the restriction to conventional cable television operators, which would exclude other MVPDs, or to cable operators that have been in the MVPD market for more than five years, have extensive resources, and have entered into exclusive contracts for programming. ${ }^{44}$

In contrast to the FCC's strong preference to regulate the cable industry, the FCC declined to expand the exclusive contract prohibition to apply to non-cable-affiliated programming, e.g., content created by vertically integrated direct broadcast satellite ("DBS") operators and new MVPDs such as AT\&T and Verizon. The FCC also concluded that section 628(c)(2)(D) did not apply to terrestrially delivered programming because specific statutory language has limited the exclusive contract prohibition to content delivered via satellite. However, in light of finding that a vertically integrated cable television operator had withheld terrestrially delivered regional sports network content in San Diego and Philadelphia, the FCC nevertheless considered whether to extend the program access rules to all terrestrially delivered cable-affiliated programming. ${ }^{45}$ While the FCC has shown great concern about consumer access to content controlled by cable operators, it has no such concern that vertically integrated telephone companies would secure exclusive content distribution agreements.

\section{B. Prohibition on Content Tier-Buy Through Requirements}

The FCC limits the ability of cable operators to foist unwanted and costly content on subscribers as prerequisites for accessing desired content.

41. Id. at 17819 (finding that access to vertically integrated programming is essential for new entrants in the video marketplace to compete effectively).

42. Id. at 17810 (" $[\mathrm{W}] \mathrm{c}$ conclude that there are no good substitutes for some satellitedelivered vertically integrated programming and that such programming therefore remains necessary for viable competition in the video distribution market.").

43. Id. at 17841 (declining proposals to narrow the ban on exclusive contracts).

44. Id. at 17842 .

45. Id. at 17860 . 


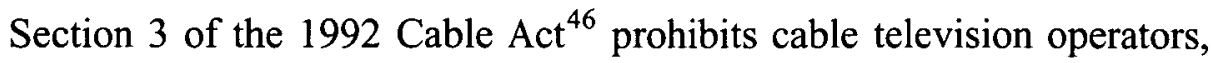
operating in a market without effective competition, from requiring subscribers to "buy through" 47 intermediate tiers of programming in order to access desired content in a higher service tier. Thus, consumers do not have to subscribe to the so-called enhanced basic service tiers, which bundle a variety of cable television programming, before they can view content offered on a per view or per channel basis, such as individual premium channels like Home Box Office.

Former FCC Chairman Kevin Martin promoted the option of content selection on an à la carte, network-by-network basis in lieu of service tiers that contain many channels of content, some of which individual consumers consider offensive. ${ }^{48}$ In contrast to these limits imposed by the FCC on cable television providers, the FCC imposes no regulations on how wireless carriers package and price access to video content.

\section{Forced Alternatives to Mandatory Set Top Box Leases}

The FCC has designed rules to enable cable television subscribers to access content via "cable ready" television sets ${ }^{49}$ without having to lease a device, known as a set top converter, that is necessary to descramble signals. The FCC prohibits cable television companies from offering set top converters that combine security functions, e.g., descrambling, with other features, such as channel selection and navigation, electronic program guides, and pay per view, on-demand access to content. This prohibition prevents cable companies from requiring all subscribers to lease set top boxes. ${ }^{50}$ With the prohibition, cable television companies can perform secu-

46. Cable Television Consumer Protection and Competition Act of 1992, Pub. L. No. 102-385, § 3, 106 Stat. 1460, 1464 (codified as amended at 47 U.S.C. $\S 543(80)$ (A) (2006)).

47. In re Sections of the Cable Television Consumer Prot. \& Competition Act of 1992, 9 F.C.C.R. 4316, 4327 (1994) ("The tier buy-through prohibition of the 1992 Cable Act prohibits cable operators from requiring subscribers to purchase a particular service tier, other than the basic service tier, in order to obtain access to video programming offered on a per-channel or per-program basis."); see also FCC Consumer Options for Selecting Cable Channels and the Tier Buy-Through Prohibition, Feb. 25, 2003, available at http://fjallfoss.fcc.gov/edocs_public/attachmatch/DOC-231469A1.pdf (FCC Fact Sheet).

48. Letter from Kevin Martin, Chairman, FCC, to Gary Flowers et al. (Aug. 22, 2007), available at http://www.fcc.gov/commissioners/previous/martin/alacarte-ltr-082207.pdf (letter to representatives of several minority public advocacy organizations).

49. In re Implementation of Section 304 of the Telecomms. Act of 1996, 20 F.C.C.R. 6794 (2005).

50. Id. at 6807-08. 
rity and digital rights management via a computer chip known as a CableCard that subscribers insert into most recent vintage television sets. ${ }^{51}$

Several cable operators unsuccessfully challenged the FCC's prohibition on set top boxes providing both security and non-security functions. On two occasions, ${ }^{52}$ the D.C. Circuit affirmed the FCC on several grounds. The court refused to consider petitioners' statutory claim that a difference exists between set top converter boxes and other equipment within the context of section 629(a) of the Communications Act, which states that the FCC "shall not prohibit any [MVPD] from also offering converter boxes, interactive communications equipment, and other equipment used by consumers to access multi-channel video programming." 33 The court characterized the petitioners' claim as illogical: "[I]f integrated set-top boxes are not 'converter boxes,' as we held in General Instrument, then they must be 'other equipment,' a possibility we did not address there. And if integrated boxes are 'other equipment,' then section 629(a)'s second sentence prevents the FCC from barring cable operators from offering them." 54

The court refused to consider this statutory claim on two procedural grounds: (1) section 629(a) established a sixty-day time period for any petitions for review of applicable Commission orders; and (2) the petitioners never presented this issue for consideration by the FCC and therefore section 405 of the Communications Act precludes raising the issue on appeal. The court upheld the FCC's integration requirement against the petitioners' argument for abandoning the requirement. While CableCard compatible television sets had become commonplace, few consumers used CableCards. The court held that "there was nothing unreasonable about the FCC's conclusion that 'the competitive reasons that led the Commission to impose the integration ban have not been eliminated by the developments in the market." ",55

The court also rejected the claim that the FCC arbitrarily exempted DBS operators from the integration ban. The court upheld the exemption based on the FCC's interpretation of the statutory criteria identifying instances

51. Charter Commc'ns, Inc. v. FCC, 460 F.3d 31 (D.C. Cir. 2006) ("[A] CableCARD ... plugs into a slot in a host navigation device, permitting the device to perform both the security and non-security functions.").

52. See id.; Gen. Instrument Corp. v. FCC, 213 F.3d 724 (D.C. Cir. 2000) (affirming the FCC's statutory authority to require separation of security and other set top converter functions); In re Implementation of Section 304 of the Telecomms. Act of 1996, 13 F.C.C.R. 14775 (1998).

53. 47 U.S.C. $\$ 549$ (a) (2006).

54. Charter Commc'ns, 460 F.3d at 37-38.

55. Id. at 41 (citing In re Implementation of Section 304 of the Telecomms. Act of 1996, 20 F.C.C.R. 6794 (2005)). 
where an MVPD allows alternatives to its set top box: a DBS is exempt when an MVPD "supports the active use by subscribers of navigation devices that: (i) operate throughout the continental United States, and (ii) are available from retail outlets ... throughout the United States that are not affiliated with the [MVPD]." " The court noted that DBS operators have met the requirements while "the vast majority of cable subscribers remain dependent upon non-portable converter boxes available only from their cable companies. ${ }^{, 57}$ In addition, the court rejected the cable operators' claims that increased facility-based competition, e.g., video program delivery from telephone companies, has encouraged cable companies to offer consumers every possible equipment alternative.

[W] hatever the theoretical incentives, the FCC found that the realworld result that section 629(a) commanded it to assure-the commercial availability of navigation devices from vendors unaffiliated with MVPDs-has not arrived. ${ }^{58}$

Additional objections about unforeseen costs that cable companies would incur failed to persuade the court:

The Commission also took steps to minimize industry costs, both by extending the implementation deadline from 2006 to 2007, and by promising to reconsider eliminating the ban altogether should the cable and consumer electronics industries achieve a downloadable security solution capable of providing common reliance without requiring the physical separation of security and nonsecurity functions. ${ }^{59}$

Cable operators have largely thwarted the Congressional mandate to give consumers alternatives to the operator-leased devices. However, while a competitive market for such devices has not evolved and few consumers even know about the CableCard option, recent innovations in digital video recorders may incorporate many of the features provided by the cable operators. Recent FCC decisions suggest that cable operators will no longer succeed in stalling compliance with section 629 of the Communications Act. ${ }^{60}$

56. 47 C.F.R. $\S 76.1204(a)(2)(2005)$.

57. Charter Commc'ns, 460 F.3d at 43.

58. Id. at 44.

59. Id. at 42

60. See In re Implementation of Section 304 of the Telecomms. Act of 1996, 20 F.C.C.R. 6794 (2005); see also In re Comcast Corp., 22 F.C.C.R. 228 (2007). 


\section{REASONS WHY WIRELESS CARRIERS SHOULD BEAR CONTENT NONDISCRIMINATION REQUIREMENTS LIKE THOSE BORNE BY CABLE OPERATORS}

Given wireless carriers' practice of marketing handsets bundled with service, the concentrated nature of the industry, and the rewards accruing from walled gardens, the FCC should subject wireless carriers to the same sort of nondiscrimination rules applied to cable operators. Because wireless handsets likely will become a competitive alternative to televisions and computer terminals, regulatory parity requires that vertically integrated wireless ventures bear similar burdens as cable operators if both type of ventures have similar incentives and abilities to exploit market power.

\section{A. Public Benefits and Harms from Bundling Wireless Service with Handsets}

United States wireless carriers can restrict the versatility and utility of handsets primarily because most subscribers acquire subsidized handsets in exchange for a two-year service commitment ${ }^{61}$ and carrier-imposed contractual limitations on handset use. Wireless subscribers have grown accustomed to acquiring "free" or inexpensive handsets. Perhaps this benefit offers ample compensation even though wireless service rates factor in the cost of the subsidy and subscribers incur substantial financial penalties for changing carriers before completion of the two-year service commitment. ${ }^{62}$

However, wireless carriers can reduce the versatility and the utility of the handset by locking users' access to content and locking out content providers' access to users. Here is a list of existing lock-out strategies:

Locking handsets so that they cannot access competitor networks (by frequency, transmission format, firmware or software). In the U.S. carriers even lock handsets designed to allow multiple carrier access by changing an easily inserted Subscriber Identity Module ("SIM");

Using firmware "upgrades" to "brick," i.e., render inoperative, the handset or alternatively disable third-party hardware and software;

Disabling handset functions, e.g., Bluetooth, Wi-Fi access, Internet browsers, GPS services, and email clients;

61. In re Implementation of Section 6002(B) of the Omnibus Budget Reconciliation Act of 1993, No. 08-27, 2009 WL 151633, 113 (Fed. Commc'ns Comm'n 2009).

62. The fixed-term service contracts and ETFs are traditional tactics of the industry to provide a discount upfront and increase sales. $I d$. 
Specifying formats for accessing memory, e.g., music, ringtones, and photos;

Creating "walled garden" access to favored video content of affiliates and partners; and

Using proprietary, non-standard interfaces difficult for third parties to develop compatible applications and content. ${ }^{63}$

The FCC needs to restrain wireless carriers from imposing limitations on handsets that have nothing to do with legitimate network management and everything to do with favoring affiliated content providers over third party service providers. These safeguards should stipulate that subscribers have a right to use any technically compatible handset to access any available source of content, software, or computer application whether or not affiliated with the wireless carrier providing the link. ${ }^{64}$

Long ago, the FCC rejected any attempt by wireline carriers to limit, block, or disable access by handsets bought from unaffiliated suppliers. ${ }^{65}$ Consumers take for granted the right to buy and operate their own telephones for accessing wireline networks, and the same principle should ap-

63. AT\&T, Wireless Data Service Terms and Conditions, http://www.wireless.att. com/learn/messaging-internet/media-legal-notices.jsp (last visited Apr. 22, 2009) (listing prohibited uses under its plan and the consequences of violations); see also AT\&T, Acceptable Use Policy, http://www.corp.att.com/aup/ (last visited Apr. 22, 2009). The policy spells out a range of activities:

AT\&T prohibits use of the IP Services in any way that is unlawful, harmful to or interferes with use of AT\&T's network or systems, or the network of any other provider, interferes with the use or enjoyment of services received by others, infringes intellectual property rights, results in the publication of threatening or offensive material, or constitutes Spam/E-mail/Usenet abuse, a security risk or a violation of privacy.

Id.

But see Letter from Ben Scott, Policy Dir. \& Chris Riley, Policy Counsel, Free Press, to Michael J. Copps, Acting Chairman, FCC (Apr. 3, 2009), available at http://fjallfoss.fcc.gov/prod/ecfs/retrieve.cgi?native_or_pdf=pdf\&id_document $=6520205185$ (opposing AT\&T decision to block wireless subscribers from activating Skype VoIP software when using the AT\&T network, but allowing such software when subscribers have access to Wi-Fi networks (ex parte communication regarding WC Docket No. 07-52)).

64. Rob Frieden, Hold the Phone: Assessing the Rights of Wireless Handset Owners and Carriers, 69 U. PITT. L. REV. 675, 720-25 (2008).

65. See Hush-a-Phone v. United States, 238 F.2d 266, 269 (D.C. Cir. 1956) (ordering the FCC to eliminate telephone company tariff restrictions on customers' right to attach non-electronic acoustic devices to telephones). In 1968 the FCC extended the right to include attachment of electronic devices. In re Use of the Carterfone Device in Message Toll Tel. Serv., 13 F.C.C.2d 420 (1968), recon. denied, 14 F.C.C.2d 571 (1968). 
ply for access to wireless networks. ${ }^{66}$ In the Carterfone policy of 1968 , the FCC specifically mandated all wireline telephone companies to allow subscribers to attach any technically compatible device. ${ }^{67}$

Already many purchasers of Apple iPhones and other cellphones have resorted to self-help ${ }^{68}$ tactics to eliminate manufacturer or carrier-imposed limitations on the handset's versatility, features and on access to third party applications and content. Rather than allow carriers to punish subscribers for engaging in such tactics, the FCC should establish a process to certify handset technology to allow any handset, operating in the proper format and frequency, to access any carrier's network and any software application. At the very least, the FCC should forbid wireless operators from imposing handset restrictions unrelated to legitimate network management.

\section{B. The Wireless Carrier Marketplace is as Concentrated and Anticompetitive as Cable Television}

The FCC recognizes that vertical integration in video content creation and distribution requires regulatory intervention. Commercial Mobile Radio

66. See Rob Frieden, Wireless Carterfone-A Long Overdue Policy Promoting Consumer Choice and Competition (New Am. Found., Wireless Future Program, Working Paper No. 20), available at http://www.newamerica.net/files/Wireless_Carterfone_Frieden. pdf.

67. The Carterfone policy established by the FCC in 1968 requires all wireline telephone companies to allow subscribers to attach any technically compatible device. Consumers take for granted the right to attach any device to a network that is "privately beneficial without being publicly harmful." See Use of the Carterfone Device, 13 F.C.C.2d at 423; see also Pub. Util. Comm'n of Tex. v. FCC, 886 F.2d 1325, 1329 (D.C. Cir. 1989) (noting long established FCC policy that carriers and non-carriers alike have a federal right to interconnect to the public telephone network in ways that are privately beneficial if they are not publicly detrimental); In re Am. Tel. \& Tel. Co.'s Proposed Tariff Revisions, 53 F.C.C.2d 473, 477 (1975), aff'd sub nom. Mebane Home Tel. Co. v. FCC, 535 F.2d 1324, 1329 (D.C. Cir. 1976); In re Telerent Leasing Corp., 45 F.C.C.2d 204, 205 (1974), aff d sub nom. N.C. Util. Comm'n v. FCC, 537 F.2d 787 (4th Cir. 1976).

Previous FCC opposition to this principle failed to pass muster with a reviewing court that interpreted the Communications Act as mandating the right of consumers to attach equipment to the network in ways that were privately beneficial but not publicly harmful. Hush-A-Phone, 238 F.2d at 266, 269 ("The intervenors' tariffs [prohibiting the use of plastic device to enhance privacy and low volume conversations], under the Commission's decision, are in unwarranted interference with the telephone subscriber's right reasonably to use his telephone in ways which are privately beneficial without being publicly detrimental.").

68. One such tactic is "jailbreaking" the phone, which allows a user to install on his device third-party applications unapproved by the provider. See Sarah Perez, Why You Have To Jailbreak the iPhone, N.Y. TIMES, Jan. 12, 2009, http://www.nytimes.com/ external/readwriteweb/2009/01/12/12readwriteweb-why_you_have_to_jailbreak_the_iphone.html. 
Service ("CMRS") operators, FCC's term for cellular radio telephone carriers, benefit from a similarly concentrated and vertically integrated industry. The top two CMRS carriers, AT\&T and Verizon, control at least 53.4 percent of the wireless market, ${ }^{69}$ and these companies also have substantial market share in broadband wireline access, e.g., Digital Subscriber Link ${ }^{70}$ and wireline telephone service. In addition to the market power accruing from a commanding share of the wireless industry, AT\&T and Verizon vertically integrate by securing exclusive content distribution rights for carriage via their wireless networks. They horizontally integrate by bundling tripleplay $^{71}$ and quadruple-play service packages ${ }^{72}$ combining wireless service with wireline telephony, Internet access, and wireline video program access. With such a broad wingspan of packaged services, these ventures can become commingle costs with an eye toward driving out competitors with a "one-stop shop" that can result in further industry consolidation through less competition and greater market shares held by a few firms.

\section{Incentives and Rewards from Wireless Walled Gardens}

Walled gardens can yield higher revenues for wireless carriers by greatly improving the odds that subscribers either will pay for carrier-supplied content, or will view advertising supported content that appears within the carrier's walled garden. When subscribers have to undertake several navigational steps and possibly incur higher costs to access content outside the carrier's walled garden, many will make do with what their carrier provides.

For subscribers using subsidized handsets, a wireless carrier can block access to competing carriers' networks and unaffiliated content sources. The carrier typically reserves the right to impose such access restrictions via the

69. Leslie Cauley, iWeapon: AT\&T Plans to Use its Exclusive iPhone Rights to Gain the Upper Hand in the Battle for Wireless Supremacy, USA TODAY, May 22, 2007, at 1B. The top four carriers control 88.1 percent of the wireless telecommunications market and that figure will near ninety percent upon completion of Verizon's acquisition of Alltel.

70. Digital Subscriber Links provide Internet access via the copper wires initially used solely to provide narrowband telephone service. Telephone companies retrofit the wires to provide medium speed broadband services by expanding the available bandwidth by about 1500 kiloHertz. The FCC defines Digital Subscriber Line as a technology that brings highspeed and high-bandwidth information over existing telephone lines. FCC, Broadband Access for Consumers, http://www.fcc.gov/cgb/consumerfacts/dsl2.html (last modified Feb. 12, 2002).

71. In re Exclusive Serv. Contracts for Provision of Video Servs. in Multiple Dwelling Units \& Other Real Estate Devs., 22 F.C.C.R. 5935, 5398 (2007) (notice of proposed rulemaking).

72. The quadruple play refers to the combination of "video, broadband Internet access, VolP and wireless service." In re AT\&T Inc. \& Bellsouth Corp., 22 F.C.C.R. 5662, 5735 (2007). 
non-negotiable subscription agreement, which few customers read and understand. The imposition of restrictions and financial penalties for early termination of service shows that the offer of a "free" wireless handset has many strings attached and in application constitutes an installment-sales contract containing substantial restrictions on subscriber use. Yet, even for subscribers who fully own their handset, whether by completing the initial two years of "rent to own" period, or acquiring an unsubsidized unit, the FCC does not outlaw restrictions that foreclose wireless subscribers freedoms to access preferred content and software applications.

\section{THE RELEVANCE OF THE INTERNET FOUR- FREEDOMS POLICY IN THE COMCAST ORDER}

The lack of any handset attachment freedoms for wireless access contrasts with an explicit FCC endorsement of the Carterfone policy in 2005 as an integral part of what Internet access rights consumers should have. The FCC should extend regulation to wireless carriers in accordance with its Internet Four-Freedoms Policy. The FCC articulated four essential "Internet Freedoms" emphasizing nondiscrimination in the manner by which ISPs provide Internet access to end users and the delivery of content. ${ }^{73}$ The FCC expects all ISPs, regardless of corporate affiliation and technology, to provide subscribers with the freedom to: (1) access the lawful content of their choice; (2) run applications and services of their choice, subject to the needs of law enforcement; (3) connect their choice of legal devices that do not harm the network; and (4) benefit from competition among network providers, application and service providers, and content providers. ${ }^{74}$

\section{A. Applying the Four Freedoms to Network Interference}

Even though the FCC did not formalize 2005 articulation of Internet Freedoms as rules, it considers it an enforceable policy and has in fact enforced this policy against Comcast. The Commission decided that Comcast violated this policy when the company used network management techniques to choke peer-to-peer ("P2P") ${ }^{75}$ transfers even when the company experienced no congestion and could have handled the traffic without imposing delays. By a 3-2 vote, the FCC concluded that Comcast violated the

73. In re Appropriate Framework for Broadband Access to the Internet over Wireline Facilities, 20 F.C.C.R. 14986 (2005) [hereinafter 2005 Internet Policy Statement].

74. Id. at 14988.

75. Peer-to-peer file transfers involves the transfer of content between two or more participants. With the use of software, such as BitTorrent, files can arrive in a timely manner by subdividing content into smaller units that are routed simultaneously via any participating network subscriber. 
FCC's 2005 Internet Policy Statement in using software applications to block or delay subscriber P2P file transfers. ${ }^{76}$ The FCC chided Comcast for unduly interfering with Internet users' right to access the lawful Internet content and to use the applications of their choice:

\begin{abstract}
Although Comcast asserts that its conduct is necessary to ease network congestion, we conclude that the company's discriminatory and arbitrary practice unduly squelches the dynamic benefits of an open and accessible Internet and does not constitute reasonable network management. Moreover, Comcast's failure to disclose the company's practice to its customers has compounded the harm. ${ }^{77}$
\end{abstract}

Specifically, the FCC found that Comcast had deployed deep packet inspection $^{78}$ equipment throughout its network to monitor the content of its customers' Internet connections and to block specific types of P2P connections such as the use of BitTorrent software. ${ }^{79}$

Comcast used software that effectively substituted the company as the recipient of a customer's P2P file transfer session and enabled Comcast to issue a command to stop sending traffic. Comcast did this by forging socalled TCP reset packets ${ }^{80}$ even though the company could have handled the current traffic volume without tampering with anyone's network use. ${ }^{81}$ While Comcast initially disclaimed any responsibility for its customers' problems, tests conducted by the Associated Press and Electronic Frontier

76. In re Formal Complaint of Free Press \& Public Knowledge Against Comcast Corp. for Secretly Degrading Peer-to-Peer Applications, 23 F.C.C.R. 13028 (2008) [hereinafter Comcast Internet Order].

77. Id. at 13028 .

78. Deep packet is a deft technology that can "identify packets in real-time" and help a service provider to target and choke off peer-to-peer traffic. Kevin Werbach, Breaking the Ice: Rethinking Telecommunications Law for the Digital Age, 4 J. TELECOMM. \& HIGH TECH. L. 59 (2005); see also Rob Frieden, Internet Packet Sniffing and Its Impact on the Network Neutrality Debate and the Balance of Power Between Intellectual Property Creators and Consumers, 18 Fordham INTEll. Prop. Media \& ENT. L. J., No. 3. 633-675 (2008).

79. The FCC noted the intrusiveness of Comcast's tactics in policing peer-to-peer traffic: "Comcast opens its customers' mail because it wants to deliver mail not based on the address or type of stamp on the envelope but on the type of letter contained therein." Comcast Internet Order, 23 F.C.C.R. at 13051 (citations omitted).

80. Id. I 41, at 13051 (citations omitted) (describing the function and workings of Transmission Control Protocol, or TCP).

81. Id. at 13056. The FCC faulted Comcast's practice as "overinclusive" for interfering with network traffic without regard for actual evidence of congestion, times of peak usage, and types of disfavored applications. Id 
Foundation ${ }^{82}$ suggested that the company selectively interfered with subscribers' file-sharing sessions through P2P applications, a user practice that did not violate FCC rules or Comcast's service terms and conditions. ${ }^{83}$ Comcast later admitted of targeting subscribers' P2P traffic for interference ${ }^{84}$ but claimed that such interference was limited to times of network congestion. ${ }^{85}$

The FCC concluded that Comcast's practices did not constitute legitimate network management, because Comcast discriminated against specific applications without regard to whether the specific use actually caused congestion by depleting the Comcast network of sufficient bandwidth:

On its face, Comcast's interference with peer-to-peer protocols appears to contravene the federal policy of "promot[ing] the continued development of the Internet" because that interference impedes consumers from "run[ning] applications ... of their choice," rather than those favored by Comcast, and that interference limits consumers' ability "to access the lawful Internet content of their choice," including the video programming made available by vendors like Vuze. Comcast's selective interference also appears to discourage the "development of technologies"such as peer-to-peer technologies - that "maximize user control over what information is received by individuals ... who use the Internet" because that interference (again) impedes consumers from "run[ning] applications ... of their choice," rather than those favored by Comcast. ${ }^{86}$

The FCC noted that Comcast had an anticompetitive motive to interfere with customers' use of P2P applications, because such software provides Internet users with a high-quality video access alternative to cable television services. ${ }^{87}$ Such video distribution might compete with Comcast's videoon-demand ("VOD") service. ${ }^{88}$ The FCC thus concluded that Comcast's

82. Id. at 13031 (recounting the Associated Press's investigations and findings against Comcast).

83. Id. at 13032 .

84. Id. at 13031 ("Following these tests, Comcast changed its account and admitted that it targets peer-to-peer traffic for interference.").

85. Id.

86. Id. at 13052 (citations omitted).

87. Id. at 13030

88. Id. After receiving Comcast's explanations for how it will treatment subscriber traffic in a nondiscriminatory manner, the FCC expressed concerns that Comcast's network management tactics might favor the company's telephone service offering vis-à-vis Internet telephone services of unaffiliated ventures. See Letter from Dana R. Shaffer, Chief, Wireline Competition Bureau, FCC \& Matthew Berry, General Counsel, FCC, to Kathryn A. 
practices were not minimally intrusive, as the company claimed, but rather invasive in substantially impeding subscribers' ability to access preferred content and applications. ${ }^{89}$

The FCC also concluded that Comcast exacerbated the situation by failing to disclose its practices to consumers. ${ }^{90}$ Because Comcast hid the fact that it interfered with customers' use of $\mathrm{P} 2 \mathrm{P}$ applications, customers had no way of knowing who was doing what to their connections. ${ }^{91}$ As a result, the FCC found that many consumers experiencing difficulty using only certain applications would blame not Comcast, as it deserved, but rather on the applications themselves, to the detriment of the companies offering such applications in a competitive marketplace. ${ }^{92}$ A majority of the FCC Commissioners concluded that although Internet access constitutes a lightly regulated information service, Comcast's discriminatory practices so harmed consumers and competitors alike that the FCC had to curb such behavior. The FCC's pro-consumer zeal and surprise intervention contrasts with its laissez-faire attitude toward perhaps even more egregious limitations wireless carriers impose on subscribers' access to content and software applications. ${ }^{93}$

Zachem, Vice President, Regulatory Affairs, Comcast Corp. (Jan. 18, 2009), available at http://hraunfoss.fcc.gov/edocs_public/attachmatch/DOC-288047A1.pdf [hereinafter Comcast VoIP Letter]. The Commission's letter to Comcast seeks an explanation for the disparate treatment of VoIP services, particularly in light of Comcast's assertion that its VoIP service is "facilities-based." The letter appears to infer that facilities-based means that Comcast physically partitions its data bandwidth, thereby creating for its VoIP service stand alone links. For Comcast's response, see Letter from Kathryn A. Zachem, Vice President, Regulatory \& State Legislative Affairs, Comcast Corp., to Dana Shaffer, Chief, Wireline Competition Bureau, FCC \& Matthew Berry, General Counsel, FCC (Jan. 30, 2009), available at http://gullfoss2.fcc.gov/prod/ecfs/retrieve.cgi?native_or_pdf-pdf\&id_document= 6520194593. Comcast reported that a subscriber would experience a noticeable deterioration in service, including VoIP service not provided by Comcast, whenever a subscriber uses seventy percent of his or her "provisioned bandwidth" for fifteen minutes or more. Because Comcast separately provisions its VoIP service, congestion from cable modems would not affect their VoIP customers.

89. Comcast Internet Order, 23 F.C.C.R. at 13051-53.

90. Comcast's failure to disclose the company's practice to its customers has compounded the harm. Id. at 13051.

91. Id. at 13058-59.

92. Id. at 13058 .

93. See United States Senate, Committee on Commerce, Science, and Transportation, Hearings, The Consumer Wireless Experience (June 17, 2009), http://commerce.senate.gov/ public/index.cfm?FuseAction=Hearings.Hearing\&Hearing_ID=03b81ffd-ba9f-42e6-8331$7 \mathrm{c} 28 \mathrm{f} 6 \mathrm{~d} 112 \mathrm{~b} 0$. 


\section{B. Establishing FCC Jurisdiction over Internet-based Practices}

In establishing its 2005 Internet Policy Statement, the FCC made clear its intention to incorporate the Policy Statement's principles "into its ongoing policymaking activities." A4 Along with the 2005 Internet Policy Statement, the FCC released its Wireline Broadband Order that largely eschewed regulation, but warned: "Should we see evidence that providers of telecommunications for Internet access or IP-enabled services are violating these principles, we will not hesitate to take action to address that conduct." 95

Perhaps anticipating that Comcast would appeal its Order, the FCC extensively outlined its statutory authority for having substantive jurisdiction over Comcast's Internet-based practices and for reaching an administrative decision without a formal rulemaking session before adjudication. The FCC based its jurisdiction over disputes regarding discriminatory network management practices primarily on two statutory mandates: (1) section 230(b) of the Communications Act of 1934, as amended, where Congress stated the United States' policy "to preserve the vibrant and competitive free market that presently exists for the Internet" as well as "to promote the continued development of the Internet" and (2) section 706(a) of the Act, where Congress directed the FCC to "encourage the deployment on a reasonable and timely basis of advanced telecommunications capability to all Americans." ${ }^{.96}$ Comcast and other parties consider these broad statutory mandates too vague to justify the requirements the FCC decided to impose on Comcast. $^{97}$

In particular, the FCC opted to exercise jurisdiction over P2P Internet connections based on ISPs' use of "communication by wire." 98 With that direct link to the general jurisdiction conferred under Title I of the Communications Act, the FCC exercised its ancillary jurisdiction on the premise that Comcast's practices undercut national Internet policy.

The FCC rejected Comcast's argument that any regulation of network access and management violated the FCC's 27-year old policy of leaving information services unregulated: (2005)).

94. Id. at 13034 (quoting 2005 Internet Policy Statement, 20 F.C.C.R. 14986, if 5

95. In re Appropriate Framework for Broadband Access to the Internet Over Wireline Facilities, 20 F.C.C.R. 14853 (2005).

96. The Commission also invoked the following statutory provisions as further justification for its decision to assume jurisdiction and to order a remedy: Communications Act of 1934, 47 U.S.C. $\S \S 151,201,256,257,601$ (a) (2006).

97. Comcast Internet Order, 23 F.C.C.R. at 13035, 13048.

98. 47 U.S.C. $\S 152($ a) (2006). 
[T] he FCC previously indicated that it would not hesitate to take action in the event that providers violated the principles set forth in the Internet Policy Statement. Moreover, the FCC repeatedly has stated its willingness to exercise the full range of its statutory authority to ensure that providers of cable modem service meet the public interest in a vibrant, competitive market for Internet-related services. For instance, in the Wireline Broadband Order, the FCC found that it had jurisdiction over providers of broadband Internet access services and stated that "we will not hesitate to adopt any non-economic regulatory obligations that are necessary to ensure consumer protection and network security and reliability in this dynamically changing broadband era." Specifically with regard to cable modem service, in the 2002 Cable Modem Declaratory Ruling sustained by the Supreme Court in Brand X, the FCC sought comment on a wide range of statutory bases for exercising ancillary jurisdiction over cable modem service, including section 230(b) of the Act. The FCC also explicitly mentioned the blocking or impairing of subscriber access by a cable modem service provider as possible triggers for FCC "intervention." 99

While deciding to act on a case-by-case basis, the FCC held that it did not have to conduct a rulemaking or hearing to investigate and remedy Comcast's practices:

[T]o the extent that Comcast implies that our ancillary authority does not extend to adjudications but rather must first be exercised in a rulemaking proceeding, it is simply wrong. The question of whether the FCC has jurisdiction to decide an issue is entirely separate from the question of how the FCC chooses to address that issue. Perhaps more to the point, the D.C. Circuit has affirmed the FCC's exercise of ancillary authority in an adjudicatory proceeding and in the absence of regulations before. ${ }^{100}$

99. Comcast Internet Order, 23 F.C.C.R. at 13049-50 (citations omitted).

100. Id. at 13048-49 (citing CBS, Inc. v. FCC, 629 F.2d 1, 26-27 (1980) (reasoning that the Commission had, in the context of an adjudication, reasonably construed its ancillary authority to encompass television networks), aff'd, 453 U.S. 367 (1981)); In re Complaint of Carter-Mondale Presidential Comm., Inc. against the ABC, CBS \& NBC Television Networks, 74 F.C.C.2d 631, If 25 n.9 (1979) ("Our power to adjudicate complaints involving requests for access to the networks is surely 'reasonably ancillary to the effective performance of the Commission's various responsibilities." ") (quoting United States v. Sw. Cable Co., 392 U.S. 157, 178 (1968)); see also Negrete-Rodriguez v. Mukasey, 518 F.3d 497, 503-04 (7th Cir. 2008) ("An agency is not precluded from announcing new principles in an adjudicative proceeding rather than through notice-and-comment rule-making."); New York State Comm'n on Cable Television v. FCC, 749 F.2d 804, 815 (D.C. Cir. 1984) (up- 


\section{Remedying Breaches of the Internet Nondiscrimination Policy}

The FCC outlined several network management tactics that Comcast could lawfully impose on subscribers, ${ }^{101}$ including capping average users' capacity and then charging overage fees, and throttling back the connection speeds of high-capacity users (rather than any user who relies on P2P technology, however infrequently. ${ }^{102}$

Although Comcast and other ISPs had pursued each of these options, the FCC determined that Comcast had to revise its network management practices and operate more transparently. ${ }^{103}$ Within thirty days of release of the FCC's Order, Comcast had to:

Disclose the details of its discriminatory network management practices to the FCC;

Submit a compliance plan for eliminating these discriminatory management practices by the end of the year; and

Disclose to customers and the FCC the new network management practices. ${ }^{104}$

The FCC warned Comcast that non-compliance with the steps set forth in the Order would lead to immediate interim injunctive relief requiring the company to suspend its discriminatory network management practices pending a hearing. ${ }^{105}$

For cable television ventures, the FCC had grave concerns about their potential for engaging in discriminatory practices when providing Internet access to subscribers. For wireless carriers, however, it is inconsistent and suspect for the FCC not to have the same concerns about similar tactics. While consumers may have only one cable television venture available in

holding adjudicatory decision that preempted certain state and local satellite television regulations under Commission's ancillary authority).

101. Comcast Internet Order, 23 F.C.C.R. at 13057-58.

102. Id.

103. Comcast's claim that it has always disclosed its network management practices to its customers is simply untrue. Although Comcast's Terms of Use statement may have specified that its broadband Internet access service was subject to "speed and upstream and downstream rate limitations," such vague terms are of no practical utility to the average customer. Id. at 13059-60 ("Our overriding aim here is to end Comcast's use of unreasonable network management practices, and our remedy sends the unmistakable message that Comcast's conduct must stop.").

104. Id. at $13059-60$

105. Id. at 13060 . 
any particular locality, the FCC notes that alternative broadband access providers exist, ostensibly providing equivalent or more competition than that provided by wireless carriers. ${ }^{106}$ Although users can change broadband providers in an ostensibly competitive marketplace, the FCC was not content to allow market forces to punish Comcast through customer churn and migration to other carriers. Arguably, wireless carriers' discriminatory practices are more egregious in restricting, burdening, and thwarting subscribers' lawful access to content and software applications. Remarkably, even though service agreements have limited subscribers' choice to switch carriers, the FCC apparently sees no need to bind wireless carriers to the Internet Freedoms or to nondiscrimination requirements of traditional common carriers.

\section{ACHIEVING A LEVEL PLAYING FIELD AND SERVING THE PUBLIC INTEREST}

Industry observers and interested parties disagree over whether wireless carriers robustly compete, or whether four national carriers share an oligopoly with over ninety percent of combined market shares. The FCC believes in the former and repeatedly eschews regulation based on market discipline competition provides. ${ }^{107}$ Remarkably the FCC refuses to believe that the competition cable television operators face from satellite and new wireline ventures, including Verizon and AT\&T, will foreclose anticompetitive practices. The FCC has intervened to remedy anticompetitive and anti-consumer restrictions on Internet access imposed by Comcast, a largely unregulated information service provider, ${ }^{108}$ but appears willing to tolerate similar forms of blocked or restricted Internet access imposed by wireless carriers.

The FCC has articulated no legal basis for creating such lack of parity in regulation, and in its refusal to remedy anticompetitive abuses by wireless carriers. In the United States, wireless carriers have actively and aggres-

106. See In re Dev. of Nationwide Broadband Data to Evaluate Reasonable \& Timely Deployment of Advanced Servs. to All Ams., Improvement of Wireless Broadband Subscribership Data, \& Dev. of Data on Interconnected Voice over Internet Protocol (VoIP) Subscribership, 23 F.C.C.R. 9691 (2008); In re Inquiry Concerning the Deployment of Advanced Telecomms. Capability to All Ams. in a Reasonable \& Timely Fashion, \& Possible Steps to Accelerate Such Deployment Pursuant to Section 706 of the Telecomms. Act of 1996, 23 F.C.C.R. 9615, 9616 (2008); WiRELINE COMPETITION BUREAU, FCC, HIGH-SPEED SERVICES FOR INTERNET ACCESS: STATUS AS OF JUNE 30, 2007 (2008), available at http://hraunfoss.fcc.gov/edocs_public/attachmatch/DOC-280906Al.doc.

107. In re Implementation of Section 6002(b) of the Omnibus Budget Reconciliation Act of 1993, 23 F.C.C.R. 2241 (2008).

108. Comcast Internet Order, 23 F.C.C.R. at 13057-58. 
sively limited subscribers' handset flexibility and freedom with impunity. Nonetheless, the FCC has been silent on regulatory requirements for wireless carriers that provide both content and conduit for next generation ICE. Disposed to supporting marketplace competition and deregulation, the FCC has given wireless carriers carte blanche freedom to operate as though they had no regulatory burdens even for still provided conventional telecommunications services.

The FCC's unwillingness to apply consumer-protection statutes lead to uneven regulation and circumscribe consumer freedom in handset use. Rather than wait for a consumer revolt, the FCC should state that:

(1) Wireless subscribers have the right to attach any handset that complies with standards designed to protect networks from technical harm; wireless operators should bear the burden of proving that a particular handset would cause technical harm and therefore should not receive FCC certification;

(2) Wireless subscribers have the right to use their handsets to access any service, software, application and content available by subscriber imputed commands or instructions. The FCC should expressly state that wireless operators should have an affirmative duty to receive, switch, route and transmit such subscriber keyed commands or instructions; and

(3) Suppliers of software, applications, services and content accessible via wireless networks have the right to offer them to subscribers subject to a reasonable determination by carriers that such access will not cause technical harm to the carriers' networks. The FCC should reserve the right to mediate and resolve disputes over technical compatibility of any software, applications, services and content accessible via a wireless carrier network.

Additionally the FCC needs to watch out for instances of excessive market consolidation. When wireless carriers acquire market share by buying out competitors, consumers have fewer opportunities to "vote with their feet" against their existing carrier. Already, wireless carriers can engage in "consciously parallel" conduct where they offer similar terms and conditions for service. For example, no carrier offers in the U.S. a discounted rate for existing or prospective customers who already have handsets and do not need subsidized new phones. Indeed, most cellular carriers advertise how well their networks operate, without much discussion about price and service versatility. 
Lastly, the FCC needs to force wireless carriers to operate in a more transparent and forthright manner so that subscribers understand the total cost of service and the limitations imposed on their handsets. Many wireless carriers have managed to insert into consumers' bills surcharges that appear as a tax or other type of compulsory fee. Without the duty to file tariffs and standard service terms and conditions, some wireless carriers can impose unanticipated charges. When handsets can access a much larger array of ICE services, it becomes essential that wireless carriers fully disclose any offer of superior access to content and preferential access for specific content providers. Not all quality-of-service and price differentials violate a reasonable conceptualization of fairness and neutrality. On the other hand, failure to disclose discriminatory pricing and service is improper and anticompetitive.

Requiring transparency and fair dealing by carriers providing the underlying transmission capacity for ICE services serves the national interest. Unfortunately, the issue of imposing such straightforward requirements has become submerged in a larger debate about how much flexibility ISPs should have to diversify services and what regulator-created incentives are necessary to encourage investment in next generation networks. The socalled network neutrality debate ${ }^{109}$ addresses what constitutes lawful price

109. See Rob Frieden, Internet 3.0: Identifying Problems and Solutions to the Network Neutrality Debate, 1 INT'L J. COMM. 461 (2007); Rob Frieden, Network Neutrality or Bias? Handicapping the Odds for a Tiered and Branded Internet, 29 HASTINGS COMM. \& ENT. L.J. 171, 171-216 (2007); see also Barbara A. Cherry, Using Network Neutrality to Eliminate Common Carriage Threatens Free Speech and the Postal System, 33 N. KY. L. REV. 483 (2006); Brett M. Frischmann \& Barbara van Schewick, Network Neutrality and the Economics of an Information Superhighway: A Reply to Professor Yoo, 47 JURIMETRICS J. 383 (2007); Bill D. Herman, Opening Bottlenecks: On Behalf of Mandated Network Neutrality, 59 FED. COMM. L.J. 103 (2006); Mark A. Lemley \& Lawrence Lessig, The End of End-to-End: Preserving the Architecture of the Internet in the Broadband Era, 48 UCLA L. REV. 925 (2001); J. Gregory Sidak, A Consumer-Welfare Approach to Network Neutrality Regulation of the Internet, 2 J. COMPETITION L. \& ECON. 349 (2006); Adam Thierer, Are "Dumb Pipe" Mandates Smart Public Policy? Vertical Integration, Net Neutrality, and the Network Layers Model, 3 J. TeleCOMM. \& High TECH. L. 275 (2005); Barbara van Schewick, Towards an Economic Framework for Network Neutrality Regulation, 5 J. TELECOMM. \& HIGH TECH. L. 329 (2007); Tim Wu, Network Neutrality, Broadband Discrimination, 2 J. TEleCOMM. \& High TeCH. L. 141 (2003); Christopher S. Yoo, Network Neutrality and the Economics of Congestion, 94 GEO. L.J. 1847 (2006); Christopher S. Yoo, Would Mandating Broadband Network Neutrality Help or Hurt Competition? A Comment on the End-to-End Debate, 3 J. Telecomm. \& High TeCH. L. 23 (2004); Craig McTaggart, Was The Internet Ever Neutral? (Sept. 30, 2006), available at http://web.si.umich. edu/tprc/papers/2006/593/mctaggart-tprc06rev.pdf (presented at the 34th Research Conference on Communication, Information and Internet Policy, George Mason University School of Law). 
and service discrimination by ISPs, but opponents have managed to frame the debate as an unlawful attempt to impose common carrier responsibilities. While ISPs do not operate as common carriers, wireless telecommunications service providers do, in addition to their information and video programming, delivery services. The FCC faces a regulatory quandary when wireless carriers augment telecommunications with new ICE services. The carriers claim that the FCC no longer has any legal basis for regulating any wireless service, because the FCC cannot subject a single enterprise to more than one regulatory regime and because competition will prevent any anticompetitive practices. However, the onset of new services, which may qualify as something other than a common carriage telecommunications service, does not by itself vitiate or eliminate the initial regulatory requirements. When handsets offer an amalgam of telecommunications, information, and video services, the FCC and wireless carriers will need to learn how to operate in an environment where two or more regulatory regimes apply. 
BERKELEY TECHNOLOGY LAW JOURNAL 